\title{
KÖZÉP-EURÓPA FOGALMA ÉS LEHATÁROLÁSA STATISZTIKAI ADATOK TÜKRÉBEN
}

\section{Concept and Borders of Central Europe Based on Statistical Data}

$$
\text { Igari András }{ }^{1} \text { - Bálint Janka² - Pálffy Patrik }{ }^{3}
$$

\begin{abstract}
Absztrakt: Számos - általában geopolitikai indíttatású - kísérlet irányult már a történelem során a Közép-Európa fogalom meghatározására. Cikkünkben mi is egy új lehatárolás létrehozatalára törekszünk, azonban történelmi és geopolitikai megközelítés helyett statisztikai módszerekkel alakítottuk ki a térség határait. Először a térséghez kapcsolódó koncepciók gyökereit és jelenkori értelmezéseit mutatjuk be. Ezt statisztikai elemzés követi, amely során jóléti, életmódbeli és attitűdbeli adatok mentén vizsgáljuk Európa országait, és K-közép klaszteranalízissel osztjuk ôket csoportokra. Az így kapott klaszterek segítségével határozzuk meg Európa legfőbb belső határvonalait és alakítjuk ki saját Közép-Európa fogalmunkat. Konklúziónk, hogy mivel ez számos téren eltér a korábbi koncepcióktól, így javasolt a Közép-Európa fogalom újragondolása.
\end{abstract}

Kulcsszavak: Közép-Európa, geopolitika, jólét, klaszteranalízis

Abstract: Many attempts to define the concept of Central Europe have been made throughout history, usually from a geopolitical perspective. The

1 Igari András geográfus, regionális elemző, az ELTE Földtudományi Doktori Iskola hallgatója. A Szent Ignác Jezsuita Szakkollégium egykori szakkollégistája.

ORCID: https://orcid.org/0000-0003-0527-8987

A szerző további munkásságát lásd a Magyar Tudományos Művek Tára oldalán: https://m2.mtmt.hu/gui2/?type=authors\&mode=browse\&sel=10066258

${ }^{2}$ Bálint Janka az ELTE Állam- és Jogtudományi Kar joghallgatója. A Szent Ignác Jezsuita Szakkollégium jelenlegi szakkollégistája.

ORCID: https://orcid.org/0000-0002-8436-7461

3 Pálffy Patrik pszichológus, a Semmelweis Egyetem Mentális Egészségtudományok doktori iskola hallgatója. A Szent Ignác Jezsuita Szakkollégium egykori szakkollégistája.

ORCID: https://orcid.org/0000-0002-8401-8712 
aim of this paper is to create a new concept, but instead of using a historical and geopolitical approach, it uses statistical methods to define the boundaries of the region. Firstly, it presents the roots and contemporary interpretations of concepts related to the region. Secondly, it subdivides European countries into groups by K-central cluster analysis; based on welfare, lifestyle, and attitudinal data. Based on the obtained clusters, the results define the main internal borders of Europe and develop a new concept of Central Europe. In conclusion, because it differs in many aspects from previous ideas; it is advisable to rethink the concept of Central Europe.

Keywords: Central Europe, geopolitics, well-being, cluster-analysis

\section{BEVEZETÉS}

Közép-Európa egy dinamikusan változó és máig velünk élő fogalom, amelyet sokan sokféleképpen igyekeztek meghatározni. A kérdésfelvetés jelentőségét Magyarország közép-európai identitásának kiemelt szerepe adja. A történelem során a mindenkori Magyarország geopolitikai helyzetéről különböző elképzelések éltek - a nyugati kereszténységhez tartozás, a keresztény végvár képzete, a lehetséges dunai birodalom képe és egyéb elképzelések egymásra rakódása kihatott a magyar Közép-Európa értelmezésre is (ami természetesen nem egyezik meg a lengyel, cseh, német stb. értelmezésekkel). Ez a mai magyar közbeszédben ismét alapvető paradigmává vált az ország helyzetét és jellemzőit illetően. Erre a fogalomra épül a külpolitikai elköteleződésünk a NATO, az Európai Unió, de a visegrádi négyek iránt is, és ennek a fogalomnak az újraértelmezése is zajlik a Nyugat-Európától való különbözőségünket hangsúlyozó politikai közbeszédben.

Tanulmányunk arra tesz kísérletet, hogy feltérképezze a fogalom jelenkori érvényességének határait. Ennek érdekében előbb áttekintjük a fogalom történetét és jelentésének változását, majd ezt követően társadalmi, gazdasági és politikai attitűdhöz kapcsolódó mutatók statisztikai vizsgálatának segítségével arra keressük a választ, hogy meghatározható-e a térség országainak együttmozgása, és ha igen, mely országok tartoznak azonos csoportokba. Itt a módszertani áttekintést követően a rendelkezésre álló mutatókból komplex fejlettségi mutatót képzünk, majd klaszteranalízis segítségével vizsgáljuk az Európát átszelő fő törésvonalakat. Végezetül a 
fogalomhoz kapcsolódó koncepciókat összevetjük az adatelemzés eredményeivel: hipotézisünk szerint a fogalom kultúrtörténetével felhalmozott jelentésrétegek egybeesnek a jelen gazdasági-társadalmi valóságával, azaz az elméletek ma is megállják a helyüket.

\section{A KÖZÉP-EURÓPA FOGALOM TÖRTÉNETE}

Közép-Európa lehatárolása nem egyszerű feladat. Hagyományos értelemben a Németország és Oroszország közötti területet értik alatta, változó kiterjedéssel, és természetesen különbség van a tisztán földrajzi, illetve a politikai határok között is. A definíciók sokszínűségét jól mutatja, hogy Karl A. Sinnhubert egy 1954-es tanulmányában 16 Közép-Európa fogalmat hasonlít össze, és azt találja, hogy Európából az Ibériai-félsziget az egyetlen olyan térség, ami egyetlen meghatározásba sem illik bele, míg Ausztria, Csehország és Morvaország az a térség, ami az összesbe. ${ }^{4}$

Maga a Közép-Európa fogalom a XIX. század terméke, a német tudományos és politikai gondolkodásban népszerűvé váló Mitteleuropakoncepcióból eredeztethető. Eszerint Közép-Európához a kontinens középső része tartozik, amelynek centruma Németország, és lefedi az egykori Osztrák-Magyar Monarchiát, Lengyelországot, a Baltikumot és egyes értelmezések szerint a Balkánt is. A koncepció - a német hatalmi törekvések alapjaként - egészen a II. világháború végéig állt fenn. ${ }^{56}$

$\mathrm{Ez}$ a földrajzi fogalom alkalmas volt arra, hogy a magyar történelmi gondolkodásban már létező elképzeléseket magába szívja. A Közép-Európa fogalom mai értelmezésének előképeit fedezhetjük fel többek között abban a kora újkori felfogásban, ami a kereszténység védőbástyájának középkori fogalmát a magyarságra vonatkoztatta, hiszen ez a határjelleg ma is érvényes mind földrajzi-politikai szempontból (az Európai Unió határa), mind kulturálisan (római katolicizmus hagyományos keleti határa). Ilyen előkép az a felismerés is, ami Magyarország helyét a török és a német érdekszféra ütközőzónájának tartotta a XVII-XVIII. században, és amely tulajdonság a XX. század hatalmi viszonyai között is igaznak bizonyult, csak már németorosz viszonylatban. Ehhez kapcsolódik Kossuth Dunai Konföderációelképzelése is: ez a föderalista gondolat a Monarchia iránti nosztalgiában is

\footnotetext{
${ }^{4}$ SCHMIDT, 2013. 60. o.

${ }^{5}$ GÓRNY, 2015. 2. o.

${ }^{6}$ MEZŐ, 2001. 83. o.
} 
megjelenik, ami egyfajta retrospektív utópiaként is értelmezhető a térség nemzetiségeinek együttéléséről és közös fejlődéséről. ${ }^{7}$

A történelmi helyzet változásával a fogalomra is újabb jelentésrétegek rakódtak. Az I. világháború után a szétbomló birodalmak helyére a franciák elképzelése szerint egy kisállamokból álló cordon sanitaire-t húztak. Ennek célja az orosz terjeszkedés visszatartása volt a nyugat-európai államok hegemóniájának veszélyeztetése nélkül, Közép-Európa hatalmi centrumok közé zárt ütközőzóna szerepét erősítve. ${ }^{8}$ A térség kisállamai között együttműködés a kisantant formájában valósult meg, azonban ehhez a magyar kapcsolódást a revíziós törekvések teljesen lehetetlenné tették.

A II. világháború után több föderatív jellegű elképzelés is született a térség jövőjéről $1^{9}$, ám végül valósággá a térség és teljes Európa kettéosztása vált. Ekkoriban a Közép-Európa fogalom jelentőségét az adta, hogy a keleti tömbbe olvadt országok disszidens, vagy hazájukban háttérbe szorított értelmisége történelmi-kulturális alapokon igyekezett kidolgozni egy olyan fogalmat, ami tartalmi jellemzők alapján el tudja határolni a térséget a Szovjetuniótól. Tették ezt egyrészt a kor jelenségeit, különösen a forradalmakat magyarázó céllal, de abból az elköteleződésből is, hogy a demokratizálódás lehetőségét elméleti síkon alátámasszák. Oscar Halecki az 1952-es Kelet-Közép-Európa története című munkájában így fogalmaz: „a tartós béke elérhetetlen mindaddig, míg ezek az országok újra el nem foglalják hagyományos helyüket az európai közösségben."10 Milan Kundera híressé vált Közép-Európa tragédiája címet viselő esszéjében a térséget a Nyugattól erőszakkal elszakított, a nyugati értékek folyamatos veszélyeztetettségét megélő közösségként értelmezi, aminek tragédiája, hogy az általa védett nyugati értékeket maga a Nyugat is kezdi elveszíteni, ezért nem tudja támogatni ezen országok értékmegőrzési kísérleteit. ${ }^{11}$ Itt kell megemlíteni Szűcs Jenőt is, aki a cseh, magyar és lengyel államterület által alkotott régiót Európa önálló, harmadik régiójaként értelmezte. ${ }^{12}$

A döntően történettudományi fókuszú értelmezésekből egy viszonylag egységes Közép-Európa kép rajzolódik ki. A lengyel, magyar és cseh állam történetében közös, hogy részesei voltak a nyugat-európai

\footnotetext{
7 SCHMIDT, 2013. 60. o.

${ }^{8}$ NORMAN, 2014. 90. o.

${ }^{9}$ ARDAY, 2015. 2. o.

${ }^{10}$ HALECKI, 1952. 10. o.

${ }^{11}$ WHITE, 1984

12 SZÜCS, 1981
} 
kultúrának, amit a nyugati kereszténységhez tartozásuk alapozott meg, és ami a reneszánsz, a reformáció, a felvilágosodás jelenlétével folytatódott. Ezek a jelenségek és a nyugati társadalmi és gazdasági fejlődés tendenciái azonban időbeli megkésettséggel és torzult formákban, sokszor felülről irányítva és nem alulról, organikusan szerveződve jelentek meg. Mindhárom állam megtapasztalta a német és az orosz befolyás közötti egyensúlyozás szükségességét, az államiságuk létét fenyegetô erôkkel való szembenállást. A Keleten ismeretlen szabadságfogalom kiemelten jelen van történetükben, de nem elsősorban a nyugati, magánjogi értelemben, hanem a nemzeti függetlenség szinonimájaként.

Összességében a legfontosabb megállapítások közé a térség Nyugathoz való tartozásának, illetve az ezzel párhuzamosan létezô elmaradottságának leírása tartozott. Ezzel gyakorlatilag a térség értelmiségének XIX. század óta létező hagyományába is illeszkedtek, hiszen Közép-Európa társadalmi, politikai, gazdasági és kulturális elmaradottságának tematizálása a nacionalizmusok megjelenése óta központi helyet foglalt el a születőben lévő nemzeti értelmiségek gondolkodásában. Jelentőségüket többek között az adja, hogy a rendszerváltás után az általuk képviselt országok az ő elképzeléseikre is alapozva alakították meg a visegrádi országok csoportját, mintegy hitet téve egy kvázi közép-európai identitás és sorsközösség mellett.

Ezzel egy időben az elmaradottság jelenségének egy másik magyarázó erejü elmélete is megjelent - az Immanuel Wallersteinhez köthető világrendszer-elmélet. Wallerstein a régiók eltérő fejlettségét a kapitalista gazdaság rendszerében betöltött eltérő szereppel magyarázza. A leginkább rentábilis termékeket termelő centrum és a nyersanyagot és munkaerōt szolgáltató periféria rendszerébe Közép-Európa, mint félperiféria illeszkedik, vagyis a centrumhoz képest alárendelt perifériaként, de a perifériához képest centrumként viselkedik. A törésvonal ilyenfajta meghatározása illeszkedik a történelmi magyarázatokhoz, amelyek szintén kiemelik például a földrajzi felfedezésekből való kimaradást és a második jobbágyság kialakulását, ami az újkorban eltérő fejlődési pályára állította Európának ezt a régióját.

A hidegháború végével a felszabaduló országok jövőjének meghatározása miatt volt releváns a fogalom: merre orientálódjanak a kialakuló új hatalmi struktúrában? Az atlanti közösség államai számára sem volt egyértelmű, hogy milyen folyamat fog lezajlani a Nyugat felé forduló országokban. Európa elszakított testvérei zárkóznak fel az őket megillető 
helyre vagy nyugat-európai hagyományoktól idegen államok európaizálása történik $?^{13}$ A térség államaiban ekkoriban terjedt el a Kelet-Közép Európa elnevezés ${ }^{14}$ ami a német nyelvterülettől való különbségre reagált oly módon, hogy a térség államainak a Kelet-Európától való különbözőséget is hangsúlyozta. ${ }^{15}$

A KGST és a Varsói Szerződés felbomlásával a közép-európai államok számára regionális kapcsolataik erősítésére is megnyílt a lehetőség. Az együttmúködés képességének felmutatása az európai integrációhoz való csatlakozás előfeltétele is volt, így ez adott további motivációt a kapcsolatok elmélyítésére. A versengő Közép-Európa koncepciók közül végül a legmagasabb szinteken képviselt, a disszidens értelmiség által megalapozott verzió alakult politikai realitássá a visegrádi csoport megalakulásával, KözépEurópát a Csehszlovákia, Magyarország és Lengyelország alkotta térségként értelmezve. Az osztrák diplomácia elszalasztotta a lehetőséget, hogy a Habsburg-nosztalgiára építve a térséget nyugat felé bővítse ${ }^{16}$, a jugoszláv államok nem álltak készen a csatlakozásra, Románia csatlakozása az etnikai konfliktusok miatt meghiúsult, és az a lengyel elképzelés sem valósult meg, ami a lengyel befolyást a tágabb értelemben vett Közép-Európára is kiterjesztette volna.

E Közép-Európa képből az következne, hogy a visegrádi együttmúködés a részes államok természetes sorsközösségeként működik, ám ez csak részben valósult meg. Bár a nyugati orientáció szükségessége valódi érdekközösségbe kovácsolta az államokat, és ez képes volt elfedni a köztük feszülő, döntően etnikai jellegû konfliktusokat, ${ }^{17}$ e célkitűzés teljesítésével sokszor a nemzeti érdekek kerültek a csoportérdek elé. Az országok közti ellentéteket szíthatja, hogy a tagországok egymás természetes versenytársai például a német múködőtőke importjáért folyó versenyben, ${ }^{18}$ Lengyelország érdekei méretbeli túlsúlya miatt sokszor ellentétesek a kisebb államokéval és a belpolitikai változások sokszor gátlóan hatnak a hatékony együttmúködésre. Ugyancsak kihívásokat jelenthet az egyes országok közt növekedő társadalmi, gazdasági és életminőségbeli különbségek is. ${ }^{19} \mathrm{~A}$

\footnotetext{
13 ALPAN, 2007. 145. o.

14 ProbÁld, 2007. 7. o.

15 MEZÓ, 2001. 94. o.

${ }^{16}$ CABADA 2018. 167. o.

17 ARDAY, 2015. 4. o.

18 SŐREG, 2019. 29. o.

${ }^{19}$ MÁté, 2019. 158. o.
} 
visegrádi országok közötti ellentétekre való reakcióként és egy tágabb Közép-Európa fogalom manifesztálódásaként is értelmezhető például a 2015-ben megalakított Austerlitzi Háromszög Ausztria, Csehország és Szlovákia részvételével. Ezekben az érintett országok szociáldemokrata kormányai a lengyel és magyar nacionalista erőktől való eltávolodás lehetőségeit is keresték. Megemlíthetjük még a Három Tenger Kezdeményezést, ami egy 2016-ban indult, lengyel vezetéssel megvalósuló, észak-déli irányú együttmúködés, amely kísérteties hasonlóságot mutat a két világháború közötti ún. Międsymorze (Intermarium) elképzelésre, ami Lengyelország Közép-Európa feletti hegemónia megvalósítását szolgálta volna. ${ }^{20}$

\section{A KÖZÉP-EURÓPA FOGALOM TÖRTÉNETE KÖZÉP-EURÓPA A STATISZTIKAI ADATELEMZÉS TÜKRÉBEN}

Kutatásunk további részében azt tárjuk fel, hogy a jelenlegi társadalmi-gazdasági jellemzők miként viszonyulnak a fent bemutatott fogalmakhoz, és hogy ezek alapján miként határolhatjuk le és miként jellemezhetjük Közép-Európát. Statisztikai adatelemzésünkön alapuló vizsgálatunk egyes lépéseit és eredményeit mutatjuk be, amelyeket végül összevetünk az előbbi fejezetben taglalt Közép-Európa koncepciókkal. Célunk, hogy a kutatásunk segítségével megvizsgáljuk az egyes elméletek jelenlegi alkalmazhatóságát és aktualizáljuk azokat.

\subsection{A használt mutatók és módszerek bemutatása}

Elemzésünk során az alapsokaságot 40 európai ország jelentette (lásd 1. sz. táblázat), amely a kontinens legtöbb államát jelenti, kivéve a kifejezetten miniállamoknak számító országokat, valamint a számos európai ország által el nem ismert, kevés és sokszor bizonytalan hátterű statisztikai adatokkal rendelkező Koszovót.

Az országokat a 22, a jólét fogalmához (társadalmi és gazdasági fejlettséghez, az egészségügyi helyzethez és életvitelhez), valamint politikai attitűdhöz kapcsolódó mutató mentén hasonlítottuk össze (a mutatókat, valamint forrásukat, időpontjukat és csoportosításukat lásd a Mellékletben). Kutatásunk során az adatokon több statisztikai elemzési módszert

${ }^{20}$ CABADA, 2018. 173. o. 
végeztünk el azon célból, hogy feltárjuk Közép-Európa helyzetét Európán belül, továbbá meghatározzuk azt, miképpen elkülönül-e a kontinens többi térségétől.

\begin{tabular}{|c|c|c|c|c|}
\hline Albánia & $\begin{array}{c}\text { Egyesült } \\
\text { Királyság }\end{array}$ & Horvátország & Málta & Románia \\
\hline Eusztria & $\begin{array}{c}\text { Észak- } \\
\text { Macedónia }\end{array}$ & Izland & Moldova & Spanyolország \\
\hline Belgium & Észtország & Írország & Montenegró & Svédország \\
\hline $\begin{array}{c}\text { Bosznia és } \\
\text { Hercegovina }\end{array}$ & Finnország & Lengyelország & Németország & Svájc \\
\hline Bulgária & Fehéroroszorsz & Lettország & Norvégia & Szerbia \\
\hline Ciprus & Franciaország & Litvánia & Olaszország & Szlovákia \\
\hline Csehország & Görögország & Luxemburg & Oroszország & Szlovénia \\
\hline Dánia & Hollandia & Magyarország & Portugália & Ukrajna \\
\hline
\end{tabular}

1. sz. táblázat. A vizsgálatba bevont európai országok köre. Forrás: saját gyújtés.

Egyrészt 11 mutatóból komplex jólléti mutatókat számítottunk ki. Ehhez először egyirányosítottuk a mutatókat aszerint, hogy a társadalmi konszenzusnak megfelelő kedvező értékek mindig magasabbak legyenek a kevésbé kedvezőknél. Ez azon mutatóknál volt hasznos, ahol a magasabb érték alapvetően kedvezőtlenebb jelenségre utal (például munkanélküliségi ráta, csecsemőhalandósági ráta). Ezt követően normalizáltuk az adatokat, hiszen az eltérő mértékegységű és nagyságrendű mutatókat legegyszerűbb módon ennek segítségével hasonlíthatjuk össze. Mindennek lényege, hogy az adott mutató esetén az egyes országok értékeit a maximum és minimum értékek intervallumán értékeljük és ahol minden esetben 0 és 1 közötti értéket kapunk. Ezen értékeket átlagoltuk az egyes országok esetén és végül 100-zal megszoroztuk a könnyebb interpretálhatóság érdekében: így az összevont mutatóink elméleti maximum értéke 100, míg az elméleti minimum 0 lett. ${ }^{21}$ Adathiány esetén átlagolással szűrtük ki a problémát.

${ }^{21}$ NeMES NAGy, 2005. 219. o. 
Ezután az adatokat klaszteranalízisnek vetettük alá. Ennek lényege, hogy az egyes megfigyelési egységeket (jelen esetben a vizsgálatba vont országokat) egy n-dimenziójú térben helyezzük el, amelyben a dimenziók a vizsgálatba vont mutatók (jelen esetben a 22 mutató) számával egyeznek meg. Ezen hipertérben az egyes megfigyelési egységek távolsága kerül meghatározásra, ami alapján végül csoportokat alakítunk ki olyan módon, hogy az egyes csoportokba az egymástól lehető legkisebb távolságra lévő országok kerüljenek. Jelen esetben az ún. K-közép klaszterezést használtunk, amelynek lényege, hogy előre megadjuk a végső klaszterek számát, majd iterációs lépések segítségével elérjük, hogy a klaszterekbe tartozó országok között a lehető legkisebb társadalmi-jóléti értelemben vett távolság legyen. Hogy minél részletesebb és sokszínúbb térbeli képet kapjunk, az eljárás során először kettő, majd három, négy, öt, hat, hét és végül nyolc klasztert állítottunk be. Arra számítottunk, hogy a különböző csoportosítások segítségével képet kapunk arról, hogy hol húzódnak Európa főbb belső társadalmi határai, és hogy ezek mennyire vannak összhangban az elméleti bevezetőben bemutatott kultúrtörténeti felosztásokkal. Előzetes feltételezésünk az volt, hogy a két klasztert elkülönítő csoportosítás a legfőbb törésvonalat mutatja be, és ahogy haladunk a nagyobb klaszterszámú modellek felé, a kevésbé fontos, de még így is meghatározó törésvonalak is megjelennek. Hipotézisünk szerint létezik olyan felosztás, amely alapján Közép-Európa elkülöníthető a kontinens más nagyrégióitól.

\subsection{Európa országainak komplex fejlettségi vizsgálata}

A fentebb felsorolt mutatókat több nagy csoportba sorolhatjuk. Jelen fejezetben kifejezetten a jóléti mutatókkal, azon belül is a társadalmigazdasági és egészségügyi fejlettség mutatóinak térbeliségével foglalkozunk behatóbban. Ezekben közös jellemző, hogy a posztmodern globalizálódó világban társadalmi konszenzus van a téren, hogy pozitív, avagy negatív képzettársításokat kötünk hozzájuk. Természetesen a pozitív és negatív képzettársításokat számos kritikával illethetjük (például az urbanizációs index esetén valóban a minél magasabb érték-e a pozitív?), azonban jelen vizsgálatunkban a tudományos kánonnak megfelelően használjuk az egyes mutatókat.

A kérdéses változók alapján az országokat sorba rendezve azt kapjuk, hogy a pozitív szélsőértékeket döntően nyugat- és észak-európai országok foglalják el (például Izland, Luxemburg és Svájc többször is), míg a negatív 
szélsőértékek jellemzően kelet-európai és balkáni országokból származnak (például Moldova, Románia, Albánia, vagy éppen a krónikus betegségben elhalálozó 65 évesnél nem idősebbek esetén Magyarország) (ld. 2. táblázat). Nem szabad azonban megfeledkeznünk arról, hogy több mutató esetén részleges adathiány lépett fel, ami döntően pont az elmaradottabb, keletvagy délkelet-európai országokat érintette.

\begin{tabular}{|c|c|c|c|c|c|}
\hline Mutatók & $\begin{array}{c}\text { Elemszá } \\
\text { m }\end{array}$ & $\begin{array}{l}\text { Pozitív } \\
\text { szélsőért } \\
\text { ék }\end{array}$ & Ország & $\begin{array}{l}\text { Negatív } \\
\text { szélsőért } \\
\text { ék }\end{array}$ & Ország \\
\hline $\begin{array}{l}\text { Egy főre jutó GDP } \\
\text { (PPP/foo) }\end{array}$ & 40 & 107.641 & Luxemburg & 5.711 & Moldova \\
\hline $\begin{array}{l}\text { Képzettség - } \\
\text { Egyetemi (tertiary) } \\
\text { képzettek a } 25-64 \\
\text { éves korosztályon } \\
\text { belül }(\%)\end{array}$ & 34 & 46,9 & Írország & 17,8 & Románia \\
\hline $\begin{array}{l}\text { Szolgáltatások és } \\
\text { ipar részaránya a } \\
\text { GVA-ból }(\%)\end{array}$ & 40 & 0,3 & Luxemburg & 19,0 & Albánia \\
\hline $\begin{array}{l}\text { Urbanizációs index } \\
(\%) \text { - World Bank }\end{array}$ & 40 & 98,0 & Belgium & 42,6 & Moldova \\
\hline $\begin{array}{l}\text { Oktatásra fordított } \\
\text { GDP } \%\end{array}$ & 36 & 7,7 & Izland & 3,1 & Románia \\
\hline $\begin{array}{l}\text { 15-24 év közötti } \\
\text { munkanélküliek } \\
\text { aránya }\end{array}$ & 40 & 6,8 & $\begin{array}{c}\text { Németorsz } \\
\text { ág }\end{array}$ & 46,7 & $\begin{array}{l}\text { Észak- } \\
\text { Macedónia }\end{array}$ \\
\hline $\begin{array}{l}\text { Csecsemőhalandósá } \\
\text { g / } 1000 \text { fó }\end{array}$ & 39 & 1,0 & Izland & 11,6 & Moldova \\
\hline $\begin{array}{l}\text { Szülési anyai } \\
\text { halálozás /100.000 fő }\end{array}$ & 40 & 3 & Izland & 31 & Románia \\
\hline $\begin{array}{l}\text { Születéskor várható } \\
\text { élettartam }\end{array}$ & 39 & 83,6 & Svájc & 71,7 & Moldova \\
\hline $\begin{array}{l}\text { Krónikus betegségek } \\
\text { miatti halál } 65 \text { év } \\
\text { alatt } / 100.000 \text { fö }\end{array}$ & 31 & 75,9 & Svájc & 255,7 & $\begin{array}{l}\text { Magyarorsz } \\
\text { ág }\end{array}$ \\
\hline $\begin{array}{l}\text { Egészségügyre } \\
\text { fordított GDP\% }\end{array}$ & 40 & 11,9 & Svédország & 5,6 & Románia \\
\hline
\end{tabular}

2. sz. táblázat: A felhasznált adatsorok elemszáma, szélsőértékei és a szélsőértéket elérô államok a 2010-es évek második felében Forrás: World Bank, 2019 és Eurostat, 2019 alapján saját szerkesztés. 
Végeredményben a 11 változóból 3 fejlettségi mutatót számítottunk: az összevont jóléti mutató mellett a mutatócsoportot kettéosztva ún. egészségügyi fejlettségi mutatót, illetve társadalmi-gazdasági fejlettségi mutatót (csoportosítást lásd 2.1. fejezet). Az egészségügyi és a társadalmigazdaság fejlettség mutatónak területi képe bár nagy vonalakban hasonlít egymásra (azaz mindkét esetben a nyugat-európai országok értékei magasabbak, szemben Kelet-, és Délkelet-Európa országainak visszafogottabb értékeivel), ugyanakkor több alapvető különbség is felfedezhető.

Egyrészről a társadalmi-gazdasági fejlettség terén fokozatosan, északnyugat felől dél és kelet felé csökkenő értékek figyelhetők meg. Mindez egyrészt a szocializmus évtizedei alatt lemaradó, majd a 2000-es évektől dinamikusan fejlődő Közép-Európa javuló, illetve a 2008-as válság által kifejezetten negatívan érintett Mediterráneum stagnáló eredményeinek - és így a két országcsoport egymáshoz való közelítésének - tudható be. ${ }^{22}$ (Természetesen Közép-Európa térségét, illetve azon belül a visegrádi országokat is súlyosan ás időben is elhúzódóan érintette a válság, ${ }^{23}$ azonban a Földközi-tenger térségének visszaesése ezt is bőven meghaladta). A társadalmi-gazdasági mutatók terén a legrosszabb értékekkel a NyugatBalkán országai rendelkeznek: mindez a magas munkanélküliségnek, az alacsony gazdasági fejlettségnek, továbbá az elkésett urbanizációs és gazdaságszerkezeti átalakulás együttes hatásának köszönhető, amelyeket tovább erősített a délszláv háború visszavető szerepe.

Másrészről az egészségügyi fejlettség esetében a vasfüggönytől nyugatra eső térségek államainak együttmozgása figyelhető meg (igaz e téren is megfigyelhető az észak-dél egyenlőtlenség), míg attól keletre pedig egy nyugat-keleti lejtő bontakozik ki. Európa vasfüggönytől keletre eső felében kifejezetten jelentős egyenlőtlenségeket találunk: a térség országai körében az egészségügyi fejlettség értékei közti átlaghoz viszonyított relatív szórás $37 \%$; ugyanez Nyugaton 8\%. Ez és a térképek mutatta mintázatok alapján feltételezhető, hogy az egykori szocialista blokk egyáltalán nem egységes, és élesedő határvonalak figyelhetők meg Közép-Európa, Délkelet-Európa (azaz a Balkán) és a hagyományos értelemben vett Kelet-Európa között (ld. 1. és 2. ábrák).

22 IGARI, 2018. 185. o.

${ }^{23}$ SÖREG, 2019. 29. o. 
Közép-Európa fogalma és lehatárolása statisztikai adatok tükrében

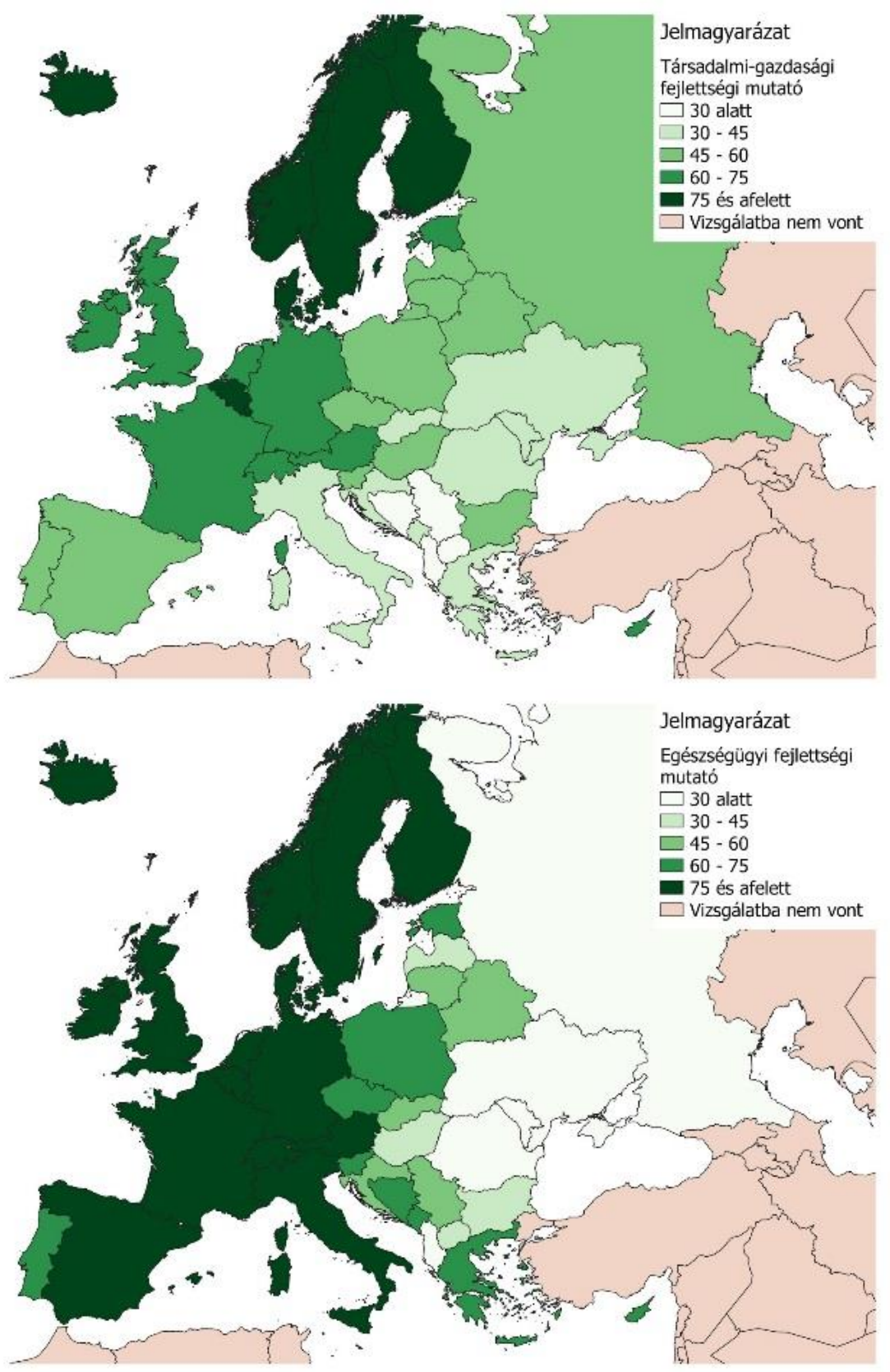

1. és 2. sz. ábra: Európa országainak társadalmi-gazdasági fejlettségi és egészségügyi fejlettségi mutatói. Forrás: Saját szerkesztés 


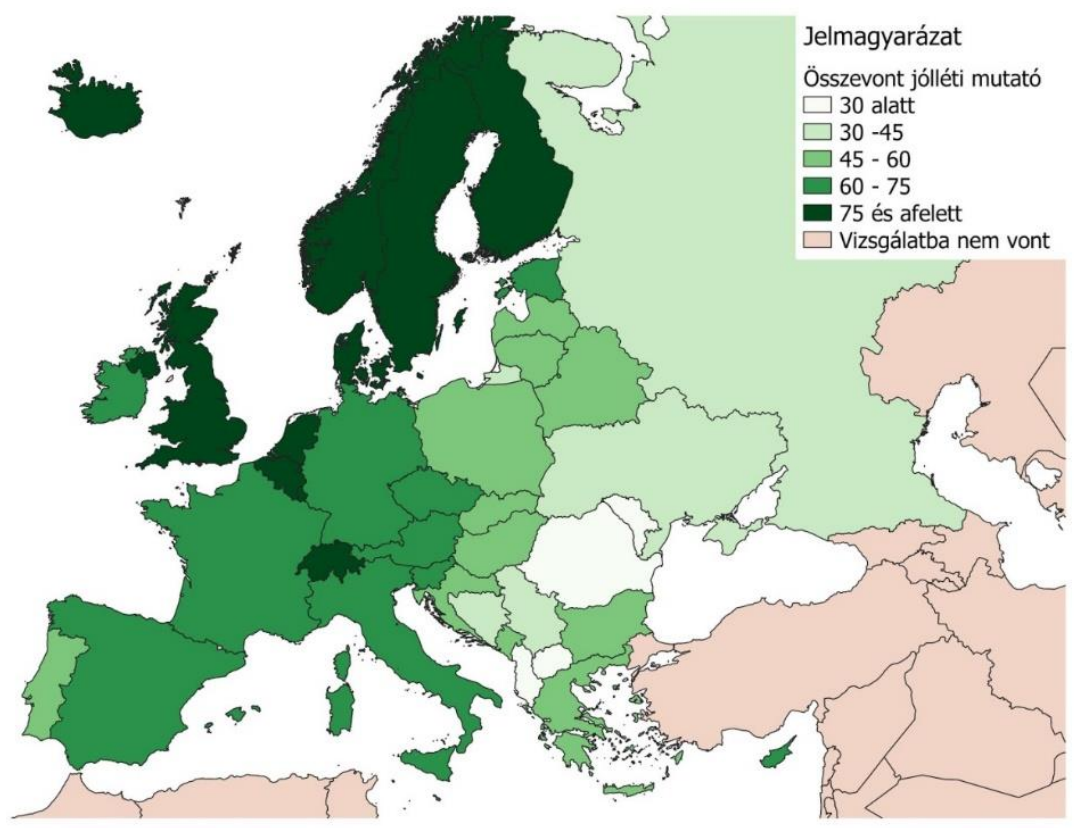

3. sz. ábra: Európa országainak összevont jólléti mutatója. Forrás: Saját szerkesztés

A kétfajta fejlettségi mutatócsoport eredőjeként összeálló összevont jólléti mutató eredménye is a fentebb taglalt jellemzők segítségével írható le: bár megfigyelhetô a nyugat-kelet ellentét, azonban egy fokozatos, Északnyugat-Európából induló fejlettségi lejtő is látható (lásd 3. sz. ábra). Közép-Európáról számos információ nyerhető ki ez alapján: egyrészt Csehország, Szlovénia és Észtország Nyugat-Európához való közelítése (és a Mediterráneum országainak utolérése, vagy lehagyása), illetve két nemUniós állam (Belarusz és Montenegró) felzárkózása az együttmúködésben résztvevő országok közé. Ezzel szemben megfigyelhetők Románia kifejezetten gyengébb értékei, amelyek elsősorban az egészségügy terén való lemaradásnak köszönhetők. Megfigyelhető tehát, hogy a jóléti változókból képzett összevont komplex mutatók alapján nem határolható le egyértelműen Közép-Európa: egyrészt külső határainak meghatározása is nehézkes (a térség nyugati határának meghatározása még valamelyest meghúzható, azonban keleti és délkeleti irányba jóval elmosódottabb 
mindez), másrészt mert megfigyelhető az országcsoporton belül is egy nyugat-keleti fejlettségbeli lejtő.

\subsection{Európa lehetséges felosztásai - Közép-Európa helyzete}

Második módszerként Európa 40 országát tehát az ún. K-közép klaszteranalízisnek vetettük alá. Az ezekre kapott eredmények alapján arra következtethettünk, hogy mely törésvonalak a legjelentősebbek és melyek kevésbé markánsak, azaz hol húzódnak a kontinenst átszelő elsődleges és másodlagos határvonalak. Kutatási témánkhoz igazodva kiemelten foglalkoztunk Közép-Európa megjelenésével, kiterjedésével. A tanulmány terjedelmi korlátai miatt eltekintünk az összes felosztás részletes elemzésétôl, azonban utalunk az egyes klaszteranalízisek eredményei közti eltérésekre.

Amennyiben a kontinenst két részre osztjuk a klaszteranalízis segítségével, úgy egyértelmúen kirajzolódik a nyugat-keleti megosztottság, ami csaknem az egykori vasfüggönynél szeli ketté a kontinenst. (4. sz. ábra) Ez alól három kivétel van: a nyugathoz húzó Csehország és Szlovénia, illetve másik oldalról a 2008-as válság során különösen meggyengült Görögország. Ez a felosztás jelzi, hogy az Európát évszázadokig meghatározó és 1945 után különösen megerősödő határvonal nem tűnt el napjainkra, hanem továbbra is a kontinens legfőbb választóvonala maradt. Ugyanakkor Csehország és Szlovénia átkerülése a nyugati klaszterbe - amely már az összevont jóléti mutató értékeiben is megjelent - jelzi, hogy van átmenet a két országcsoport között. Az egyes csoportok esetén nem meglepő módon a Nyugati csoport értékei kedvezőbbek mind az egészségügyi fejlettség, mind a társadalmi-gazdasági fejlettség terén: kivétel nélkül minden mutató terén egy, a nyugati klaszterbe tartozó ország található a ranglista élén. 


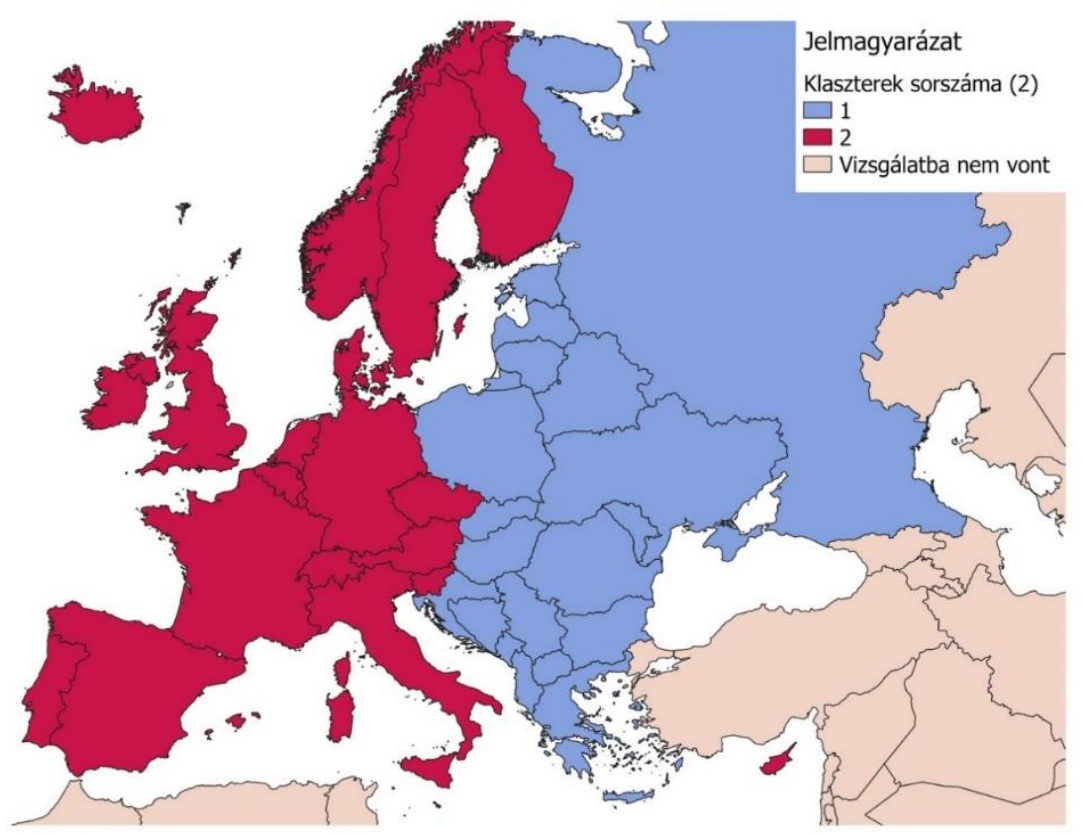

4. sz. ábra: Európa főbb országcsoportjai a két klaszterre elvégzett klaszteranalízis eredményeként. Forrás: Saját szerkesztés

Amennyiben a kontinenst négy klaszterre bontjuk, az alábbi országcsoportokat találhatjuk: a Észak-Európa és Belgium; Nyugat-Európa; a Mediterráneum és Közép-Európa jelentős része; valamint Kelet- és Délkelet-Európa jelenti a 4 csoportot (lásd 5. sz. ábra). Magyar szemmel különösen érdekes, hogy hazánk az 1-es (kelet-európai) csoportba került, míg a többi visegrádi-ország, Horvátországgal, Montenegróval és Észtországgal karöltve a 2-es csoportba. Mindez elsősorban Magyarország kelet-európai jellemzőkkel bíró egészségügyi mutatóinak köszönhető. 


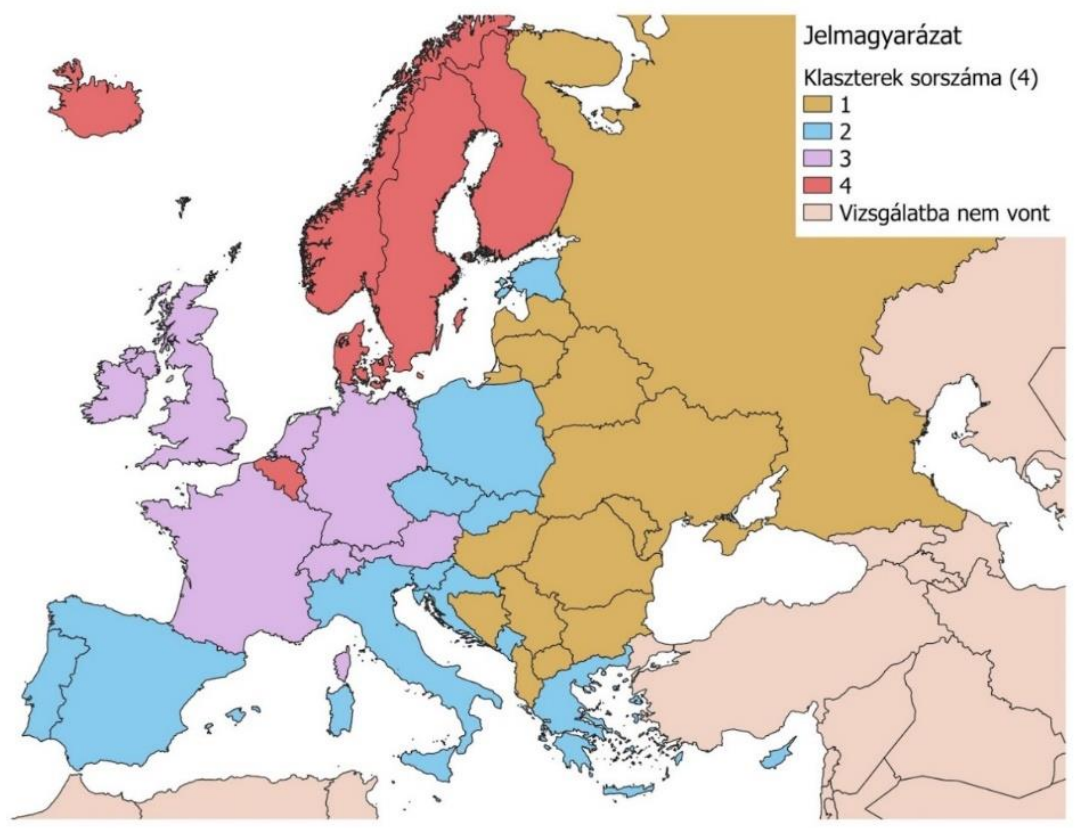

5. sz. ábra: Európa főbb országcsoportjai a négy klaszterre elvégzett klaszteranalízis eredményeként. Forrás: saját szerkesztés

Mindez a felosztás kísértetiesen hasonlít Európát centrumra, félperifériára és perifériára osztó modellekre (lásd 1. fejezet). NyugatEurópa számít egyértelműen a centrumnak, ezen belül is kiemelkedik valamelyest Észak-Európa. Közép-Európa és a Mediterráneum hagyományos félperifériának számítanak, míg Kelet- és Délkelet-Európa már perifériának. Ez a jólléti mutatók tükrében is kimutatható, hiszen az összevont mutatók értékei a centrum felől keletnek és délnek fokozatosan romlanak. Ezen felosztásban tehát Közép-Európa még mindig nem különálló egység, hanem Dél-Európával egy csoportban található (igaz, öt klaszter esetén már részben szétválnak) és hozzá hasonló értékeket vesz fel: ők együtt alkotják a Nyugat-Európát övező félperiférikus gyűrűt.

Amennyiben azonban hat klasztert állítunk be, már kikristályosodnak a kontinens regionális országcsoportjai: Észak-Európa (Belgiummal kiegészülve), Nyugat-Európa, Dél-Európa, Kelet-Európa (a Balkán több országával: Románia, Bulgária, Észak-Macedónia, Albánia kiegészülve), Közép-Európa, illetve a környezetüktől eltérő csoportba tartozó BoszniaHercegovina, Montenegró és Ciprus (lásd 6. sz. ábra). 


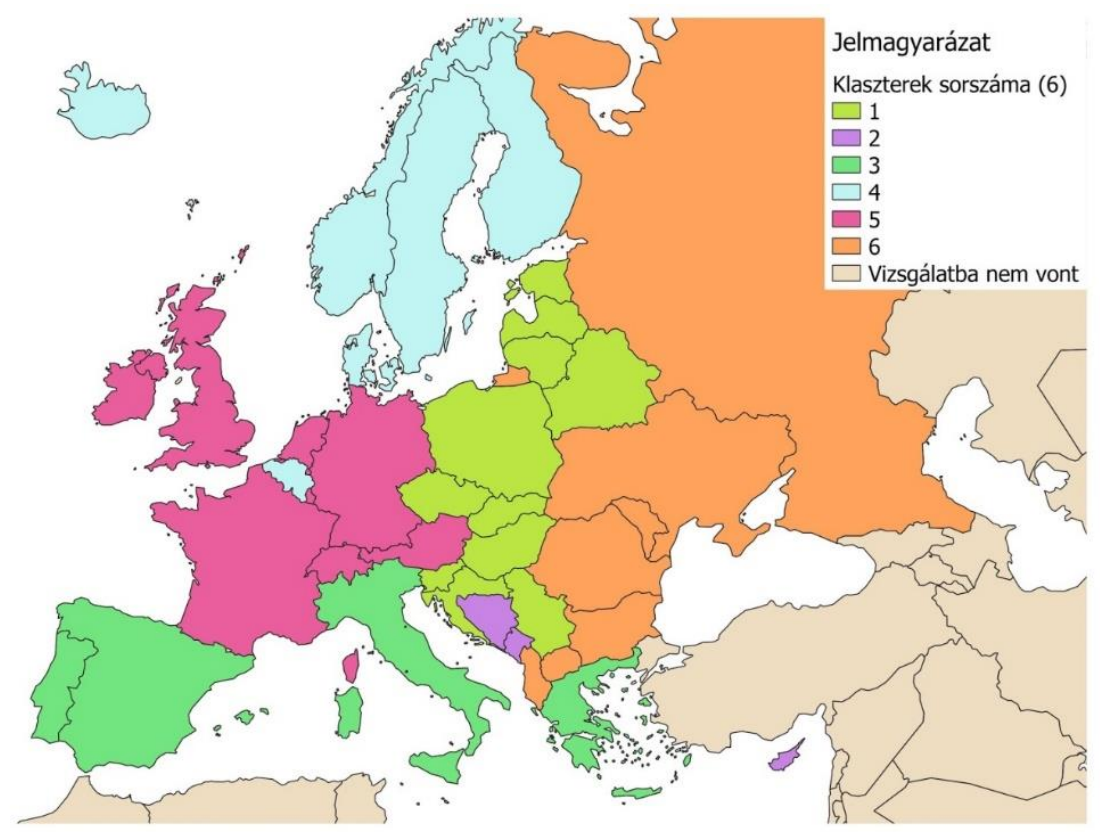

6. sz. ábra: Európa főbb országcsoportjai a hat klaszterre elvégzett klaszteranalízis eredményeként. Forrás: Saját szerkesztés

Ezen felosztásban tehát már megjelenik egy közép-európai klaszter, amelynek tagjai a V4-ek országain túl Szlovénia, Horvátország, Szerbia, a Balti államok, illetve Belarusz. Utóbbi ország relatív nyugatra húzása az Európában egyedülálló, az orosz gazdaságtól és gázimporttól függő (és a nyomott árak miatt a nagyfokú eladósodást is ideig-óráig elkerülő), a szovjet rendszer és a piaci igények hibridjeként létrejött belarusz gazdasági modellnek köszönhető, amely a FÁK-országokénál kedvezőbb jóléti mutatókat eredményez. ${ }^{24}$

Az így megállapított Közép-Európa nyugati határa már megegyezik az egykori vasfüggönyével, azonban keleti és délkeleti határa már nem feltétlenül igazodik az eddig megismert felosztásokhoz: sem a V4-ekkel, sem pedig az Európai Unióhoz csatlakozó volt szocialista államokkal nem azonos ez a csoport: ez utóbbi esetén tehát jóval nehezebben artikulálható az elhatárolás módja és oka. Mindez nagy hasonlóságot mutat a 2.2.

\footnotetext{
${ }^{24}$ KARÁCSONYI - KOCSI - BOTTLIK. 2017, 125. o.
} 
fejezetben megállapított eredményekkel, miszerint Közép-Európa nyugati határa egyértelmúbb, történelmileg jobban igazolható, mint a keleti-délkeleti.

Amennyiben ennél több klasztert hozunk létre, a kép egyre mozaikosabbá válik: hét klaszter esetén már felbomlanak a korábban egybefüggő regionális tömbök, hiszen Portugália is az egykori KözépEurópa klaszterből maradt országokhoz lesz hasonló, míg nyolc klaszter esetén még tagoltabbá válik Európa térképe.

\subsection{Közép-Európa koncepciók az eredmények tükrében}

Már az I. fejezetben bemutatott koncepciók összehasonlítása során felfedezhettünk egyfajta bizonytalanságot, hiszen az eltérő értelmezések eltérő területegységeket fedtek le. Amennyiben összevetjük a koncepciókat a statisztikai adatok elemzésével, azt találjuk, hogy Közép-Európa lehatárolása a felhasznált mutatók alapján sem egyértelmú, illetve számos olyan megközelítés létezik, amelyben a térség nem jelenik meg, mint Európa különálló régiója. A kontinens legfontosabb törésvonala ugyanis továbbra is a Nyugat-Kelet differenciálódás, amelyet jelentőségében a centrumfélperiféria-periféria viszonyrendszer követ, és csak hat klaszter esetén jelent meg egy összefüggő, Közép-Európával lényegében megegyező térség: ennek jellemzői nem olyan markánsak, mint Nyugat-, Kelet-, Észak-, avagy DélEurópának (hiszen ezeknél késóbb, csak hat klaszter esetén rajzolódik ki), azonban mégis egységes egészként is kezelhető.

Ezen térség határai nyugaton az egykori vasfüggöny mentén húzódtak, azonban keleten és délkeleten egészen Szerbiáig és Belaruszig tartanak (azaz olyan országokig, amelyeket ritkán kezel a szakirodalom Közép-Európa részeként), míg északon a Balti államok, délen pedig Szlovénia és Horvátország is ide tartozik. Ugyanakkor Románia és Bulgária, mint Európai Uniós tagországok, már kimaradtak.

Ami a (magyar) politikai szférában napjainkban meghatározó V4-eket illeti, megállapítható, hogy a hasonló történeti emlékezet és napjaink politikai törekvései ellenére ezen országok nem kezelhetők egységes országcsoportként: volt olyan felosztás (öt klaszter esetén), amikor a négy ország három különböző klaszterba került. Egyedül a már említett hat klaszteres felosztásban kerültek egy csoportba az országok, azonban itt is több más országgal karöltve. Különösen a nyugat felé közelítő Csehország tér el társadalmi-gazdasági jellemzői alapján a többi országtól, míg Magyarország több megközelítés szerint is inkább kelet-európai 
jellegzetességekkel bír. Ugyancsak elvetendők a 2. fejezetben bemutatott további, Közép-Európához kapcsolódó értelmezések is. Így sem a német gyökerű Mitteleurope-koncepció, sem a térséget az Osztrák-Magyar Monarchiával azonosító elképzelés, sem a lengyel Három Tenger Kezdeményezés nem állja meg a helyét napjainkban. Csakúgy, mint azok az elméletek, amelyek szerint Közép-Európa azon volt szocialista országok csoportját jelenti, amelyek a szovjet befolyás alól felszabadulva napjainkra az Európai Unió és/vagy a NATO tagországaivá váltak.

Mindezek alapján úgy véljük, érdemes lenne a Közép-Európa koncepciókat újragondolni, és a napjainkban gyakori V4-ek szerinti lehatárolást nem csupán északi és déli (Balti államok, illetve Horvátország és Szlovénia), hanem akár keleti és délkeleti irányba is kibővíteni. Természetesen itt más jellegű problémák merülnek fel: az eltérő politikai környezet, az Európai Unióhoz való tartozás kérdése, az eltérô történelmi tapasztalat, avagy a kulturális (vallási) különbségek okán például Belarusz Közép-Európához való sorolása merész javaslatnak tűnik.

\section{KONKLÚZIÓ}

Kutatásunk során azt a célt tűztük ki magunk elé, hogy összehasonlítsuk Közép-Európa elméleti koncepcióit az európai államok mai helyzetével, és megállapítsuk, mennyiben érvényesek az elméletek ma, le tudják-e írni a jelenkori helyzetet. Hipotézisünk szerint a különböző jelentésrétegekből összeálló Közép-Európa kép lefedi a mai társadalmigazdasági valóságot.

Közép-Európa elméleti koncepcióinak felgöngyölítése során egy összetett, földrajzi, történelmi, gazdasági, társadalmi, kulturális, nyelvi és egyéb jellemzők által meghatározott fogalommal találkoztunk. Megállapítható, hogy Közép-Európa fogalma időben és térben sem állandó és hogy az elméletek és a társadalmi valóság kölcsönösen hatottak egymásra. A közép-európai államhatárok és politikai berendezkedések változása szükségszerűen indukálta az elméletek fejlődését, de például a tudományos elméletek közvetlenül hatottak a Visegrádi Együttmúködés megalakulására, ami a további tudományos kutatásoknak is irányt adott.

A statisztikai elemzés alapján az egyik fontos levonható megállapítás, hogy a társadalmi jellemzőkben lévő eltérések a földrajzi térben is manifesztálódhatnak: tehát az egymáshoz közel eső országok hasonló értékekkel bírnak. Kutatásunk továbbá bebizonyította, hogy a kontinens 
legjelentősebb egyenlőtlensége a Nyugat-Kelet differenciálódás, ezt követi a centrum-félperiféria-periféria viszonyrendszer, majd hat klaszter esetén a makroregionális csoportosulás. Utóbbi alapján egyértelműen kirajzolódott egy közép-európai csoport, ami egy különálló területi egységet alkot Európán belül. Bár jellemzői nem olyan markánsak, mint Nyugat-, Kelet-, Észak-, avagy Dél-Európának (hiszen ezeknél később, csak 6 klaszter esetén rajzolódik ki), de egy egységet alkot. Az ebbe a csoportba tartozó államok köre azonban nem egyezik meg az elméleti bevezetóben felvázolt legfontosabb koncepciókkal. Olyan egyedi csoportosulásról van szó, amely ötvözi néhány hagyományos csoportosítás tagjait (például közel áll a volt kommunista országok köréhez vagy az Unió 2004-es bővítéséhez) de teljes mértékben nem felel meg azoknak. Figyelemre méltó, hogy a magyar közbeszédben és politikában egyeduralkodónak tekinthető, elméletileg is jól megalapozott, a V4-ek alkotta szűk Közép-Európa értelmezés társadalmigazdasági szempontból meghaladottnak tekinthető, hiszen a csoport tagjai között legtöbbször nagyobbak a különbségek, mint amik őket más országoktól elválasztják. Ez alapján megállapítható, hogy bár Magyarország kétségkívül azonos történelmi és kulturális gyökerekkel rendelkezik a környező országokkal, a közelmúlt és a jelen gyors változásai akár egy-két évtized alatt át tudják rajzolni Európa régióinak térképét.

Ezen következtetések alapján kutatásra érdemes kérdés, hogy Magyarország milyen jellemzők tekintetében egyezik meg a középeurópainak tekinthető államokkal, különösen, ami a balti államokkal való, eddig fókuszban nem lévő hasonlóságokat illeti.

\section{FELHASZNÁLT IRODALOM}

ARDAY Lajos (2015): Közép-Európa és a Visegrádi Négyek, International Relations Quarterly, Vol.6. No.1. (Letöltve: 2019. 01. 05.)

ALPAN, BAȘAK Z. (2007): Intellectual and Political 'Europe': Rupture or Continuity in Central Europe? In: Stanislav J. Kirschbaum szerk.: Central European History and the European Union. Palgrave Macmillan, New York, 145-158. o.

CABADA, LAdislav (2018): The Visegrad Cooperation in the Context of Other Central European Cooperation Formats, Politics in Central Europe. Vol.14. No.2. (Letöltve: 2019. 01. 05.) 
GÓRNY, MACIEJ (2015): Concept of Mitteleuropa. Elérhető: https://encyclopedia.1914-1918-

online.net/article/concept of mitteleuropa (Letöltve: 2019. 01. 05.)

HALECKI, OSCAR (1952): Borderlands of Western Civilization: A History of East Central Europe. Simon Publications, Safety Harbor

IGARI ANDRÁS (2018): A tengerparti régiók változó gazdasági szerepe a 21. századi Európában, Földrajzi Közlemények, Vol.142. No.3. 177-188. o. (Letöltve: 2019. 01. 08.)

KARÁCSONYI DÁVID - KOCSIS KÁROLY - BOTTTLIK ZSOLT (szerk.) (2017): Belarus in Maps. MTA CSFK FKI, Budapest

MÁTÉ ANNA (2019): Mi fán teremnek a Visegrádi országok? - Az együttmúködés országai az alapvető gazdasági mutatók tükrében, Külügyi Műhely, Vol.1. No.1. 43-161. o. DOI azonosító: DOI: $10.36817 /$ KM.2019.1.8

MEZŐ FERENC (2001): Közép-Európa fogalmi változása térben és időben, Tér és Társadalom, Vol.15. No.3-4. 81-103. o (Letöltve: 2019. 01. 03.)

Nemes Nagy József (2005): Regionális Tudományi Tanulmányok 11 Regionális elemzési módszerek. ELTE Regionális Földrajzi Tanszék MTA-ELTE Regionális Tudományi Kutatócsoport, Budapest

Norman, Saul E. (2014): Historical Dictionary of Russian and Soviet Foreign Policy. Rowman \& Littlefield, Lanham-London

PROBÁLD FERENC (2007): Európa társadalomföldrajzi vázlata In: Probáld Ferenc - Szabó Pál szerk.: Európa regionális földrajza II. Társadalomföldrajz, ELTE Eötvös Kiadó, Budapest 5-32. o.

SCHMIDT ANDREA (2013): Közép-Európa - vasfüggönytől az európai integrációig In: Grünhut Zoltán - Vörös Zoltán szerk.: Az átalakuló világrend küszöbén. Publikon Kiadó, Pécs, 59-81. o.

SŐREG KRISZTINA (2019): Növekedési lassulások és a függő piacgazdaságok elmélete Kelet-Közép-Európa esetében - Magyarország gadasági növekedése a Visegrádi Csoport fejlődési útja fényében, Külügyi Múhely, Vol.1. No.1. 20-43. o. DOI azonosító: DOI: 10.36817/KM.2019.1.2 SZƯCS JENŐ (1981): Vázlat Európa három történeti régiójáról, Történelmi Szemle, Vol.24. No.3. 313-359. o.

White, EDmund (1984): The Tragedy of Central Europe by Milan Kundera, Translated from the French by Edmund White, New York Review of Books, Vol.31. No.7. (Letöltve: 2019. 01. 03.) 


\section{MELLÉKLET}

\begin{tabular}{|c|c|c|c|}
\hline Mutató & Időpont & Adatforrás & Mutatócsoport \\
\hline $\begin{array}{l}\text { Csecsemőhalandóság (1000 születésre } \\
\text { jutó) }\end{array}$ & 2017 & World Bank & $\begin{array}{l}\text { Egészségügyi } \\
\text { fejlettség }\end{array}$ \\
\hline $\begin{array}{l}\text { Szülési anyai halálozás (100.000 szülésre } \\
\text { jutó) }\end{array}$ & 2015 & World Bank & $\begin{array}{l}\text { Egészségügyi } \\
\text { fejlettség }\end{array}$ \\
\hline Születéskor várható élettartam (év) & 2017 & World Bank & $\begin{array}{l}\text { Egészségügyi } \\
\text { fejlettség }\end{array}$ \\
\hline $\begin{array}{l}\text { Állami egészségügyi kiadások (GDP \%- } \\
\text { ban) }\end{array}$ & 2016 & World Bank & $\begin{array}{l}\text { Egészségügyi } \\
\text { fejlettség }\end{array}$ \\
\hline $\begin{array}{l}\text { Krónikus betegségek miatti halál } 65 \text { év } \\
\text { alatt ( } 100.000 \text { főre jutó szám) }\end{array}$ & 2015 & Eurostat & $\begin{array}{l}\text { Egészségügyi } \\
\text { fejlettség }\end{array}$ \\
\hline 15-24 évesek közötti munkanélküliség (\%) & 2017 & World Bank & $\begin{array}{l}\text { Társ.-gazd. } \\
\text { fejlettség }\end{array}$ \\
\hline $\begin{array}{l}\text { Oktatásra fordított kiadások (GDP \%- } \\
\text { ban) }\end{array}$ & $\begin{array}{l}2013- \\
2017\end{array}$ & World Bank & $\begin{array}{l}\text { Társ.-gazd. } \\
\text { fejlettség }\end{array}$ \\
\hline Egy fớre jutó GDP (PPP/fó) & 2017 & World Bank & $\begin{array}{l}\text { Társ.-gazd. } \\
\text { fejlettség }\end{array}$ \\
\hline $\begin{array}{l}\text { Egyetemi képzettek a 25-64 éves } \\
\text { korosztályon belül ( } \%)\end{array}$ & 2017 & Eurostat & $\begin{array}{l}\text { Társ.-gazd. } \\
\text { fejlettség }\end{array}$ \\
\hline Urbanizációs index (\%) & 2017 & World Bank & $\begin{array}{l}\text { Társ.-gazd. } \\
\text { fejlettség }\end{array}$ \\
\hline Agrárium részaránya a GDP-ből (\%) & $\begin{array}{l}2016- \\
2017\end{array}$ & World Bank & $\begin{array}{l}\text { Társ.-gazd. } \\
\text { fejlettség }\end{array}$ \\
\hline Depressziósok aránya a lakosságban (\%) & 2014 & Eurostat & Életvitel \\
\hline Dohányzók aránya (\%) & 2017 & Eurostat & Életvitel \\
\hline Pszichoterápiára járók aránya (\%) & 2014 & Eurostat & Életvitel \\
\hline $\begin{array}{l}\text { Élettel való elégedettség (1-10 skála } \\
\text { átlaga) }\end{array}$ & $\begin{array}{l}2000- \\
2014\end{array}$ & $\begin{array}{l}\text { World Values } \\
\text { Survey }\end{array}$ & Életvitel \\
\hline
\end{tabular}




\begin{tabular}{|c|c|c|c|}
\hline Bizalom az EU-ban (\%) * & $\begin{array}{l}2000- \\
2014\end{array}$ & $\begin{array}{c}\text { World Values } \\
\text { Survey }\end{array}$ & Politikai attitűd \\
\hline Harcolna-e az országáért? (\%) & $\begin{array}{l}2000- \\
2014\end{array}$ & $\begin{array}{l}\text { World Values } \\
\text { Survey }\end{array}$ & Politikai attitűd \\
\hline A politika fontosság az életben $(\%) *$ & $\begin{array}{l}2000- \\
2014\end{array}$ & $\begin{array}{l}\text { World Values } \\
\text { Survey }\end{array}$ & Politikai attitűd \\
\hline Gyerekvállalás (db) & $\begin{array}{c}2000- \\
2014\end{array}$ & $\begin{array}{l}\text { World Values } \\
\text { Survey }\end{array}$ & Életvitel \\
\hline $\begin{array}{l}\text { Soha nem venne részt politikai } \\
\text { demonstráción }(\%)\end{array}$ & $\begin{array}{l}2000- \\
2014\end{array}$ & $\begin{array}{l}\text { World Values } \\
\text { Survey }\end{array}$ & Politikai attitűd \\
\hline A demokrácia rossz $(\%) * *$ & $\begin{array}{l}2000- \\
2014\end{array}$ & $\begin{array}{l}\text { World Values } \\
\text { Survey }\end{array}$ & Politikai attitűd \\
\hline EU-s lakosnak tartom magam $(\%) *$ & $\begin{array}{c}2000- \\
2014\end{array}$ & $\begin{array}{l}\text { World Values } \\
\text { Survey }\end{array}$ & Politikai attitűd \\
\hline
\end{tabular}

3. táblázat: A vizsgálatba vont mutatók, az adatfelvétel idôpontja, az adatok forrása, illetve a nagyobb mutatócsoport, amelybe elemzéseink során besoroltuk. *A mutató százalékos adatokat tartalmaz 4 csoportba osztva aszerint, hogy egyetért vagy sem az állítással. Az általunk készített mutató a felső két százalék összesített százalékát tartalmazza (pl. Nagyon bízom az

EU-ban + Inkább bízom az EU-ban. ** Az előző mutató készítési eljáráshoz hasonlóan készült prediktor, de az alsó két százalékot vontuk össze. Forrás: saját szerkesztés 